\title{
METHODOLOGICAL ASPECT OF THE DEVELOPMENT OF PRIMARY SCHOOL CHILDREN'S ABILITY TO UNDERSTAND MUSIC AT ART LESSONS
}

\author{
Denys Makovskiy, \\ postgraduate student, Melitopol State Pedagogical University of the Bogdan Khmelnytsky, \\ Melitopol, Ukraine
}

DOI: https://doi.org/10.31435/rsglobal_wos/31052020/7093

\section{ARTICLE INFO}

Received: 15 March 2020

Accepted: 10 May 2020

Published: 31 May 2020

\section{KEYWORDS}

understanding of music, musical educational process, primary schoolchildren, methodological aspect.

\begin{abstract}
The article provides methodological bases of the development of primary schoolchildren's ability to understand music at art lessons. According to the functions and approaches to the musical educational process of primary schoolchildren, the author has identified a component structure in the unity of four components: motivational, emotional-aesthetic, cognitive-informative and creative-activistic. A detailed description of each component is given.
\end{abstract}

Citation: Denys Makovskiy. (2020) Methodological Aspect of the Development of Primary School Children's Ability to Understand Music at Art Lessons. International Academy Journal Web of Scholar. 5(47). doi: $10.31435 /$ rsglobal_wos/31052020/7093

Copyright: (C) 2020 Denys Makovskiy. This is an open-access article distributed under the terms of the Creative Commons Attribution License (CC BY). The use, distribution or reproduction in other forums is permitted, provided the original author(s) or licensor are credited and that the original publication in this journal is cited, in accordance with accepted academic practice. No use, distribution or reproduction is permitted which does not comply with these terms.

Introduction. The current stage of modernization of school art education is connected with the introduction of a methodological basis of the content and organization of the artistic and aesthetic process in primary schools. Regarding this, the need to develop primary schoolchildren's ability to understand music at art lessons is being actualized. This ability should be oriented for the development of specific learning outcomes of the personality - knowledge, skills, abilities, formation of attitudes, experiences. The level their development allows primary schoolchildren to act properly in certain learning and life situations.

It should be noted that in the musical educational process of primary school, the development of knowledge, skills and abilities prevail over all others, because music is the only one of the most emotional forms of art. Both in the theory and practice of working with preschoolers and primary schoolchildren, the influence of music isn't used well enough, cause music has an impact on the harmonization of psycho-physiological and emotional states, development of each child's identity, awareness of their self-significance, etc. The main purpose of the musical educational process is the overall development of the children and formation of their personal attitude towards musical art. The outstanding teacher V.A. Sukhomlinsky has noted that full mental development of a child is impossible without musical education [4, 147-416].

Purpose of the study: to research methodological aspect of the development of primary schoolchildren's ability to understand music at art lessons.

Material and methods. On the basis of a systematic-structural analysis, we have determined the methodological bases of the development of primary schoolchildren's ability to understand music at art lessons as a unity of four components - motivational, emotional-aesthetic, cognitive-informative and creative-activistic. It is worth noting that the use of the systematic approach has allowed us to define the phenomenon under study as a complete dynamic system of structural components and corresponding functions. 
Research results. The essence of the motivational component of the ability to understand music is viewed in the child's personal-meaningful attitude and interest for the musical art, musical educational process, and presence of the desire for successful music-performing activity. The realization of the content of such component determines the value orientation of aesthetic emotional-sensual motives of children to experience beautiful things in music. This component plays an important role in the development of primary schoolchildren's ability to understand music at art lessons. Scientists determine the concept of "motivation" as an internal psychological activity, which organizes and plans the activity and behavior, based on the necessity to meet the need [3, 201-210]. In the process of motivation development, the need acquires one of its essential features -objectivity. The turn of a need into a motive of a specific activity takes place, when the need acquires its objectivity $[6,390]$.

Another component of the development of primary schoolchildren's ability to understand music at art lessons is the emotional-aesthetic one, which is based on the development of children's sensual sphere and musical abilities. This exact component is the most significant and voluminous one in the component structure of the development of primary schoolchildren's ability to understand music at art lessons. The essential foundation of this component is the emotional state of a child as well as the development of his or her musical abilities. At the same time, syncretism and high emotionality are main features of the child's perception. Syncretism is manifested in the perception of musical art, which is a characteristic feature of a given school age. This feature makes it difficult for a child to analyze a piece of music but this analysis is an important condition of the educational process. The power and content of music, which reveal the most significant features of personality, affect child's attitude towards objects and phenomena of reality, create certain conditions of personality's life. These aspects influence the entire psychological state of the personality, being clearly manifested in personality's actions, creating the so-called general peculiar characteristic [2,12]. Thus, scientific research proves that emotional understanding of music is the ability to perceive, feel, and react directly and emotionally to the content of a piece of music and to musical education as a whole. When working with children, it is not so important to pay more attention to the identification and development of musical abilities. On the contrary, the main thing is the reaction to the music and its emotional and figurative perception.

Cognitive-informative component of the development of primary schoolchildren's ability to understand music at art lessons presupposes that they have an elementary level of musical awareness and competence. The development of primary schoolchildren's ability to understand music through the means of musical art becomes effective on the condition that children are provided with theoretical and practical information, which is interesting for them, encourages them to acquire musical knowledge and develop skills at art lessons. While learning, primary schoolchildren develop not only value-motivational orientations, they also acquire a systematic knowledge of musical art. This knowledge system promotes the formation of ability to understand music, stimulates active creative activity, as well as the need for practical work. While developing primary schoolchildren's ability to understand music it is important to use information and communication technologies in order to visualize the educational information. We agree with I. Dychkivska that the accumulation of knowledge necessarily implies its application, which leads to the formation of a certain style of thinking, skills, reproductive and creative level of implementation of theoretical issues and concepts of learning into practical activity [1, 183]. Thus, cognitive-informative component of the ability to understand music includes active and harmonious interaction in an interpersonal-creative space, ability to act constructively in a situation of creative interpersonal communication, ability to build harmonious relationships with all participants of musical education process.

Creative-activistic component of the development of primary schoolchildren's ability to understand music at art lessons is manifested in the tendency to creative self-expression in the process of musical activity, as well as in the development of creative skills and abilities. Musical creativity is an effective tool in the process of disclosing creative abilities and potential of a child. Any creativity involves a kind of human activity, which is characterized by the presence of a problem-creative task, that is, the presentation of educational material in a way that provokes a creative situation. Musical creativity can appear in the process of both individual and group form of musical education of children of primary school age. Prominent musicians-innovators of their time thought active forms of musical activity to be very important ones. They include children orchestra, plastic music improvisation, performance of music, etc. The mentioned above component involves not only mastering the skills and abilities of performance, but also the ability of children for self-expression by means of vocal, 
instrumental performance and dance movement activities. B. Teplov emphasizes that "it is necessary to involve all children without exception into creative activity, because it is very useful for the overall development, is completely natural for the child and meets his or her needs" [5, 134]. Thus, the identification of structural components of primary schoolchildren's ability to understand music at art lessons in a certain way also affects the development of their mental features.

Conclusions. Recent studies provide the foundation for us to say that the development of ability to understand music plays the role of children's motivation for understanding music at art lessons, influences the emotional and communicative sphere of a child (which contributes to the formation of child's emotional sphere and sensitivity), stimulates development of musical knowledge, skills and abilities (development of metro-rhythmic feeling, memory, imagination), engages active musical creativity (which promotes creative development of personality), increases self-esteem and development of the ability to understand others.

\section{REFERENCES}

1. Dychkivska, I. (2004). Innovative pedagogical technologies Kiev: Academic Publishers. [in Ukraine].

2. Legkov, E. (1960). Beliefs and their development while educating children Kiev: Rad. school. [in Ukraine].

3. Machtakova, O. (2013). Motivation: from antiquity to postmodernism. Kiev: Atlant. [in Ukraine].

4. Sukhomlinsky, V. (1976). How to educate a real person Kiev: Rad. school. [in Ukraine].

5. Teplov, B. (1985). Psychology of musical abilities. Moscow: Pedagogy. [in Russian].

6. Trofimov, Yu., Rybalka, V., Goncharuk, P. (2003). Need and motivation subsystem. Psychology. Kiev: Publishing house Lybid. [in Ukraine]. 